\title{
PENGARUH PERSEPSI KUALITAS PRODUK DAN DIFFERENSIASI PRODUK TERHADAP PERILAKU PERPINDAHAN MERK SEPEDA MOTOR YAMAHA DI KABUPATEN PURWAKARTA
}

\author{
Oleh : \\ Adi Sopian, SE - Program Studi Manajemen \\ Indra Maulana, SE., MM - Program Studi Manajemen
}

\begin{abstract}
Business competition makes consumers benefit from the many brands that sell the same product with different variations. therefore the bargaining power of consumers against producers become more powerful, because the consumer has a variety of alternative product variations that can meet their needs. Various alternative options of this product can lead consumers to switch brands from one brand to another brand. The purpose of this study was to determine how much influence the perception of product quality and product differentiation on the displacement behavior Yamaha brand motorcycles in the town of Purwakarta. This research includes research into descriptive. The collection of primary data through questionnaires by sampling using Probability Sampling technique. Data analysis technique used in this research is the validity of the data, the reliability of the data, the normality of the data, mutikolieritas, heterokedastisitas. While the test design using multiple linear regression data analysis, the correlation coefficient, the coefficient of determination while to test the truth of the hypothesis performed with partial and Test Simultaneous Test.

The results showed that the perception of product quality and product differentiation has a strong relationship to the displacement behavior Yamaha brand motorcycles in Purwakarta. This is evidenced from the results obtained in testing the hypothesis that $t$ value perception of the quality of the product $=4,640>t$ table $\neg=1,984$. While the value of product differentiatin $t=4,226>$ 1,984. With the level of significance of both is $(0.000$ and 0.000$)$ less than 0.05. while simultaneously test results obtained arithmetic sum of $95735 F$ and $F$ table at 3:09 with a significance level greater than 0:00 <0.05. The value of the correlation coefficient of 0776 as well as the coefficient of determination $=60.2 \%$ subsequent multiple regression equation obtained was $Y=20,329+-0150-0303 X 1+X 2+e$. It means that any increase in the perception of the product quality $1 \%$ then the displacement behavior of the brand will decrease by 0.150 . And if the product differentiation increased by $1 \%$, the displacement behavior of the brand will be down 0.303.
\end{abstract}

Keywords: Perception of Product Quality, Product Differentiation, Brand Switching Behavio 


\section{PENDAHULUAN \\ Latar Belakang.}

Globalisasi dewasa ini membawa dampak baik bagi dunia usaha, terlebih para pelaku usaha menyikapinya secara positif dengan mengembangkan usahanya melalui pendekatan perkembangan budaya, ilmu pengetahuan dan teknologi. Pelaku bisnis sadar bahwa konsumen sangat jeli, cerdas dan selektif dalam menyikapi perilaku bisnis saat ini.Dengan teknologi yang berkembang cepat, konsumen dengan mudah memperbarui pemahaman tentang produk melalui perangkat-perangkat teknologi.Pemahaman konsumen terhadap produk ini menjadi sangat penting.Perkembangan teknologi juga memicu produsen untuk terus berinovasi dan mendifferensiasikan produknya, sehingga produknya menjadi lebih bervariasi dan berbeda dengan pesaing.

Konsumen juga diuntungkan oleh banyak merk yang menjual produk yang sama dengan berbagai variasi. Oleh sebab itu Posisi tawar konsumen terhadap produsen menjadi lebih kuat, karena konsumen memiliki beragam alternatif pilihan variasi produk yang dapat memenuhi kebutuhannya.Berbagai alternatif pilihan produk ini dapat memicu konsumen untuk beralih merk dari satu merk ke merk lainnya.Perilaku perpindahan ini dinamakan brand switching behavior.

\section{Rumusan Masalah}

Berdasarkan latar belakang di atas, maka perumusan masalah dalam penelitian ini adalah sebagai berikut :

1. Bagaimana pengaruh persepsi kualitas produk terhadap perilaku perpindahan merk sepeda motor Yamaha

2. Bagaimana pengaruh differensiasi produk terhadap perilaku perpindahan merk sepeda motor Yamaha

3. Bagaimana pengaruh persepsi kualitas dan differensiasi produk terhadap perilaku perpindahan merk sepeda motor Yamaha

\section{Tujuan Penelitian}

Berdasarkan perumusan masalah yang ada maka tujuan penelitian ini sebagai berikut :

1. Untuk mengetahui bagaimana pengaruh persepsi kualitas produk terhadap perilaku perpindahan merk sepeda motor Yamaha

2. Untuk mengetahui bagaimana pengaruh differensiasi produk terhadap perilaku perpindahan merk sepeda motor Yamaha

3. Untuk mengetahui bagaimana pengaruh persepsi kualitas dan differensiasi produk terhadap perilaku perpindahan merk sepeda motor Yamaha.

\section{Kegunaan Penelitian}

Adapun manfaat dari penelitian ini adalah sebagai berikut :

\section{Bagi Diri Pribadi}

Untuk menambah pengetahuan penulis di bidang pemasaran khususnya tentang perilaku konsumen, disamping itu penulis diharapkan mengetahui masalah yang dihadapi oleh perusahaan dengan mengaplikasikan teori-teori yang telah diperoleh dibangku kuliah, terutama tentang pengaruh persepsi kualitas dan differensiasi produk terhadap perilaku perpindahan merk.

\section{Bagi Perusahaan}

Untuk membantu memecahkan masalah dan mengantisipasi masalah yang ada di Perusahaan hingga hasil penelitian ini dapat digunakan sebagai salah satu masukan guna mengatasinya

\section{Bagi Pihak Lainnya}

Untuk memberikan sumbangan pemikiran-pemikiran kepada pihak-pihak yang berkepentingan dengan masalah pengaruh persepsi kualitas produk dan differensiasi produk terhadap perilaku perpindahan merk dari suatu produk.

\section{KAJIANPUSTAKA, KERANGKA PEMIKIRAN DAN HIPOTESIS \\ Kajian Pustaka \\ Perilaku Konsumen}

Menurut Solomon (2013:31) "The field of costumers behavior a lot of ground : it is the study of the processes involved when individual or groups select, purchase, use, or dispose of product, service, ideas, or experience to satisfy need desires".

Perilaku konsumen diartikan sebagai perilaku seseorang konsumen, kelompok konsumen atau masyarakat luas yang selalu berubah dan bergerak sepanjang waktu.Sedangkan menurut Kotler dan Keller (2009:166) Perilaku Konsumen adalah studi tentang bagaimana individu, kelompok, dan organisasi memilih, membeli, menggunakan, dan bagaimana barang, jasa, ide, atau pengalaman untuk memuaskan kebutuhan dan keinginan mereka.

\section{Konsep Merk}

American Marketing Associationdalam Kotler dan Keller (2009:258) mendefinisikan merek sebagai nama, istilah, tanda, simbol atau rancangan atau kombinasi dari hal-hal tersebut. Menurut Rangkuti (2008:2)Tujuan pemberian 
merek adalah untuk mengidentifikasi produk atau jasa yang ditawarkan oleh pesaing.

\section{Perilaku Perpindahan Merk}

Menurut Kotler dan Keller (2009:190) adalah perilaku pribadi mencakup keputusan untuk berhenti membeli produk (opsi keluar) atau memperingatkan teman (opsi suara), dan beralih produk baik sementara ataupun menyingkirkan produk selamanya.Menurut Kotler dan Keller (2009:134)suatu bisnis yang sukses jika berhasil mendapatkan, menumbuhkan dan mempertahankan pelanggan (mengurangi keberalihan/ switching reduce).

\section{Persepsi Kualitas Produk}

Salah satu alasan terpusatnya perhatian perusahaan pada kualitas produk adalah karena hal tersebut merupakan dasar dari keuntungan kompetitif.Kualitas merupakan syarat bagi produk untuk masuk di pasaran Jacky dan Chew (2012:30). Tanpa adanya kualitas produk sulit bersaing di pasaran, dimana konsumen tidak akan membeli sebuah produk tanpa jaminan kualitas, contohnya penjual makanan tidak akan laris terjual jika makanan itu kurang enak. Definisi makanan yang kurang enak juga merupakan penilaian tersendiri, mungkin jika ditanyakan kepada orang lain maka jawabannya pun bisa berbeda, itu semua tergantung perspektif konsumennya masing-masing.

\section{Differensiasi Produk \\ Agar dapat dijadikan merk, produk harus differensiasikan.Produk fisik mempunyai potensi differensiasi yang beragam.Ada produk yang memungkinkan sedikit variasi dan adapula yang banyak variasi, perbedaan variasi inilah yang dapat membedakan suatu persaingan bisnis.Menurut Kotler dan Keller (2009:8) produk harus didifferensiasikan}

\section{OBJEK DAN METODE PENELITIAN} Objek Penelitian

Objek penelitian ini adalah persepsi kuaitas produk dan differensiasi produk terhadap perilaku perpindahan merk sepeda motor Yamaha. Penelitian ini dilakukan untuk memperoleh data dan informasi sebagai bukti empiris mengenai besarnya pengaruh antara persepsi kualitas produk dan differensiasi produk terhadap perilaku agar dijadikan merk, differensiasi mengukirkan identitas berbeda dan terpisah dalam kategori-kategori tertentu.Menurut Kertajaya (2004 : 148), mengatakan bahwa diferensiasi produk adalah merancang seperangkat perbedaan dalam hal konten, konteks dan infrastruktur. Semakin produk bervariasi maka semakin banyak tawaran dari variasi tersebut, yang dapat memicu pesaing melakukan hal yang sama. Maka dari itu variasi menjadi sektor penting dalam persaingan. Berdasarkan pengertian diatas maka dapat disimpulkan differensiasi adalah proses penambahan serangkaian perbedaan untuk membedakan tawaran perusahaan dengan pesaing.

\section{Penelitian Terdahulu}

1. Suzy Widiasary ISSN 1412-3126 : Analisis Perilaku Brand Switching konsumen dalam Pembelian Sepeda Motor

2. Anandhitya Bagus Arianto ISSN 16935241 : Pengaruh Atribut Produk, Harga, Kebutuhan Mencari Variasi Baru, dan Ketidakpuasan Konsumen terhadap keputusan perpindahan merk dari samsung galaxy series

3. Jeofer Pratama Sahetapy ISSN 23031174 : Differensiasi Produk, Strategy Merk Pengaruhnya Terhadap Keputusan Pembelian Meubel UD Sinar Sakti

\section{Hipotesis}

Berdasarkan kerangka pemikiran di atas, maka hipotesisnya sebagai berikut :

Persepsi Kualitas Produk dan Differensiasi Produk berpengaruh negatif secara parsial maupun simultan terhadap Perilaku Perpindahan Merk

perpindahan merk sepeda motor Yamaha di Purwakarta.

\section{Metode Penelitian}

Metode yang digunakan dalam penelitian ini adalah metode deskriptif, kualitatif yang di kuantitatifkan. Penggunaan metode ini bertujuan untuk mengetahui gejala-gejala dalam penelitian serta menjelaskan pengaruh dari suatu fenomena melalui pengujian hipotesis.Berdasarkan hal di atas maka perumusan estimasi model penelitian ini adalah 
$\mathrm{Y}=\alpha_{0}+\alpha_{1} \mathrm{X}_{1}+\alpha_{2} \mathrm{X}_{2}+\mathrm{e}$

Dimana :

$\mathrm{X}_{1}=$ Perspsi Kualitas Produk (Perceived Quality)

$\mathrm{X}_{2}=$ Differensiasi Produk (Product

Differention)

1. Operasional Variabel
$\mathrm{Y}=$ Perpindahan Merk (Brand Switching)

$\alpha_{0,1,2}=$ Parameter Regresi (Regression Parameter)

$\mathrm{e}=$ Error Estimasi (Estimation Error)

Tabel 3.1

Operasional Variabel

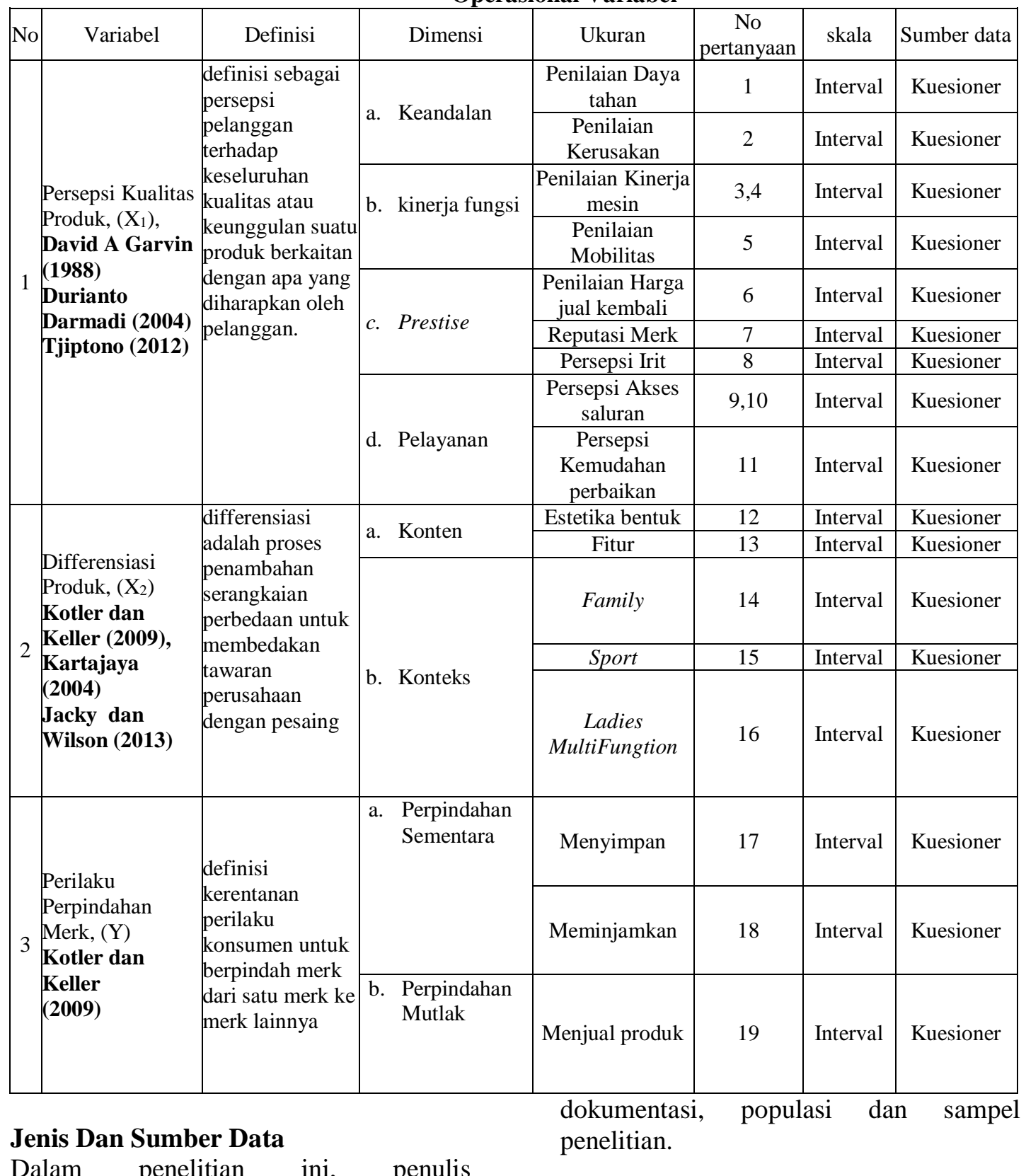

Dalam penelitian ini, penulis menggunakan dua jenis data sebagai bahan penelitian yaitu data primer dan data sekunder.

\section{Teknik Pengumpulan Data}

Untuk mendapatkan berbagai macam data yang dibutuhkan dalam penelitian ini, peneliti menggunakan beberapa teknik pengumpulan data. Teknik tersebut antara lain : Penelitian lapangan, Studi

\section{Metode analisis rancang uji}

Agar data yang dikumpulkan tersebut dapat bermanfaat, maka harus diolah dan dianalisis terlebih dahulu sehingga dapat dijadikan sebagai dasar dalam pengambilan keputusan. Adapun analisis yang digunakan sebagai berikut : analisis kualitatif dan analisis kuantitatif.

\section{Uji Hipotesis}




\section{Uji t}

Uji $\mathrm{t}$ statistik untuk menguji pengaruh antara variabel bebas terhadap variabel tidak bebas secara parsial dengan mengasumsikan bahwa variabel lain dianggap konstan.

\section{Uji F}

Uji statitis F dilakukan untuk menunjukan apakah semua variabel bebas yang dimasukkan dalam model memiliki pengaruh secara bersama-sama terhadap variabel terikat

\section{Lokasi dan Waktu Penelitian}

Lokasi penelitian ini dilakukan di Purwakarta dengan bidang pemasaran merk Sepeda Motor Yamaha yang menjadi fokus utama.Waktu penelitian dilakukan selama satu bulan, dengan membandingkan data primer dan sekunder yaitu, data penelitian lapangan dengan data dokumentasi perusahaan.

\section{HASIL PENELITIAN DAN PEMBAHASAN}

\section{Hasil Penelitian}

\section{Gambaran umum daerah penelitian}

Karakteristik dari objek penelitian yang dilakukan penulis dapat dikelompokkan ke dalam beberapa aspek, penulis akan mendeskripsikan atau mengindentifikasikan data responden berdasarkan jenis kelamin, usia, tingkat pendidikan, jenis profesi, tingkat pendapatan dan frekuensi sejarah kepemilikan sepeda motor. Jumlah respoden yang menjadi sasaran untuk pengambilan data kuesioner berjumlah 100 orang, identifikasi ini dilakukan untuk mengetahui karakteristik secara umum.

\section{Gambaran Umum Variabel Penelitian Deskripsi Variabel}

Hasil indeks jawaban responden dimana persepsi kualitas produk menyatakan bahwa rata-rata responden menyatakan netral terhadap penilaian kualitas yaitu dengan skor 55.24 kategori tersebut termasuk skor nilai cukup. Dari data tersebut terlihat juga tanggapan responden terhadap persepsi kualitas terutama pada kategori mesin tidak cepat panas, kenyamanan dalam bepergian, harga jual kembali, konsumsi bahan bakar, dan kemudahan perbaikan mandapat skor 3536 kategori tersebut termasuk skor nilai buruk, hal ini mempengaruhi tanggapan keseluruhan akan persepsi kualitas produk sepeda motor Yamaha menjadi netral.

Differensiasi menunjukan bahwa rata responden menyatakan tidak setuju terhadap penilaian differensiasi produk yaitu dengan skor 38 kategori tersebut termasuk skor nilai buruk. Dari data tersebut terlihat juga tanggapan responden terhadap differensiasi produk terutama pada kategori kelengkapan fitur, kenyamanan keluarga, pemakaian touring, dan kenyaman pemakaian wanita (untuk responden laki-laki dilihat dari segi pendapat laki-laki tentang fenomena pengguna sepeda motor yamaha) mandapat skor 30-36 kategori tersebut termasuk skor nilai buruk, hal ini mempengaruhi tanggapan keseluruhan akan differensiasi produk sepeda motor Yamaha menjadi buruk.

Perilaku perpindahan merk menunjukan bahwa rata responden menyatakan sangat setuju terhadap perilaku perpindahan merk yaitu dengan skor 86 kategori tersebut termasuk skor nilai sangat baik atau bisa diartikan perpindahan merk tinggi. Dari data tersebut terlihat juga tanggapan responden terhadap perilaku perpindahan merk dari segi responden menyimpan produk dan berpindah merk mendapat skor nilai 85 kategori tersebut termasuk skor nilai sangat baik atau bisa diartikan perpindahan merk tinggi, dari segi responden meminjamkan produk dan berpindah merk mendapat skor nilai 83 kategori tersebut termasuk skor nilai sangat baik atau bisa diartikan perpindahan merk tinggi, dari segi responden menjual produk dan berpindah merk mendapat skor nilai 90 kategori tersebut termasuk skor nilai sangat baik atau bisa diartikan perpindahan merk tinggi,

\section{Analisa Data \\ Uji Kualitas Data \\ Uji Validitas}

Hasil uji validitas diperoleh hasil bahwa semua variabel beserta indikatornya mempunyai $r$ hitung $>r$ tabel dengan 
jumlah sampel responden sebanyak 100 orang dan $r$ tabel sebesar 0.1975 .

\section{Uji Reabilitas}

Hasil Uji reabilitas diperoleh bahwa variabel-variabel persepsi kualitas produk, differensiasi produk dan perilaku perpindahan merk memiliki Cronbach Alpha masing-masing sebesar 0,733, 0,711 , 0,821. Berdasarkan nilai kritis Cronbach Alpha sebesar 0,60, maka dapat disimpulkan bahwa keseluruhan variable tersebut adalah reliabel atau handal.

\section{Uji Normalitas}

Hasil uji normalitas bahwa data dalam penelitian hubungan langsung antara Persepsi Kualitas Produk, differensiasi produk terhadap perilaku perpindahan merk berdistribusi normal.

\section{Uji Multikolinieritas}

Hasil uji multikolinieritas diperoleh bahwa tidak terdapat multikolinearitas antar variabel bebas dalam model regresi ini.

\section{Uji Heterokedastisitas}

Hasil uji heterokedastisitas diperoleh bahwa titik-titik tidak membentuk pola tertentu atau tidak ada pola yang jelas serta titik-titik menyebar di atas dan dibawah angka 0 (nol) pada sumbu Y, maka tidak terjadi heteroskedastisitas.

\section{Estimasi Model Penelitian}

a. Koefisien Korelasi antar variable independent dan dependen yaitu diketahui antara persepsi kualitas produk (X1) dengan perilaku perpindahan merk (Y) nilai signifikasi $0.000<0.05$ yang berarti terdapat korelasi yang signifikan. Dimana nilai korelasi $\mathrm{X}_{1}-\mathrm{Y}-0.776$ berarti korelasi bersifat negative atau berbanding terbalik

b. Dari hasil analisis diatas dapat dilihat bahwa koefisien determinasi $\mathrm{R}$ Square sebesar 0.602 yang memiliki arti bahwa pengaruh variabel persepsi Kualitas Produk terhadap Perilaku Perpindahan Merk adalah sebesar $60.2 \%$ dan sisanya $39.8 \%$ dipengaruhi oleh variable lain diluar model penelitian.

c. Dari hasil analisis diatas dapat dilihat bahwa model regresi linear sederhana adalah $\mathrm{Y}=20.784+-0.259 \mathrm{X}_{1}$. ini bisa diartikan konstanta sebesar 20.784 menyatakan bahwa jika tidak ada nilai persepsi kualitas maka nilai perilaku perpindahan merk 20.784 dan koefisien regresi $\mathrm{X}_{1}$ sebesar -0.259 menyatakan bahwa setiap penambahan 1 nilai persepsi kualitas produk maka nilai perilaku perpindahan merk berkurang sebesar 0.259 .

d. differensiasi produk $\left(\mathrm{X}_{2}\right)$ dengan perilaku perpindahan merk (Y) nilai signifikasi $0.000<0.05$ yang berarti terdapat korelasi yang signifikan. Dimana nilai korelasi -0.768 berarti korelasi bersifat negative atau berbanding terbalik

e. Dari hasil analisis diatas dapat dilihat bahwa korelasi R 0.768 berarti bernilai korelasi positif karena lebih dari 0 . serta koefisien determinasi $\mathrm{R}$ Square sebesar 0.589 yang memiliki arti bahwa pengaruh variabel Differensiasi terhadap perilaku Perpindahan Merk adalah sebesar $58.9 \%$ dan sisanya $41.1 \%$ dipengaruhi oleh variable lain diluar model penelitian.

f. Dari hasil analisis diatas dapat dilihat bahwa model regresi linear sederhana adalah $\mathrm{Y}=$ $18.245+\left(-0.567 \mathrm{X}_{2}\right)$. ini bisa diartikan konstanta sebesar 18.245 menyatakan bahwa jika tidak ada nilai persepsi kualitas maka nilai perilaku perpindahan merk 18.245 dan koefisien regresi $\mathrm{X}_{2}$ sebesar -0.567 menyatakan bahwa setiap penambahan 1 nilai persepsi kualitas produk maka nilai perilaku perpindahan merk berkurang sebesar -0.567 .

1. Uji Hipotesis

Dari hasil analisis diatas dapat dilihat bahwa korelasi $\mathrm{R}$ 0.815, ini berarti korelasinya bersifat positif karena lebih dari nol. serta koefisien determinasi R Square sebesar 0.664 yang memiliki arti bahwa pengaruh variabel persepi kualitas produk dan differensiasi produk terhadap perilaku perpindahan merk adalah sebesar $66.4 \%$ dan sisanya $33.6 \%$ dipengaruhi oleh variable lain diluar model penelitian.

Dari hasil analisis diatas dapat dilihat bahwa nilai model regresi linear berganda adalah

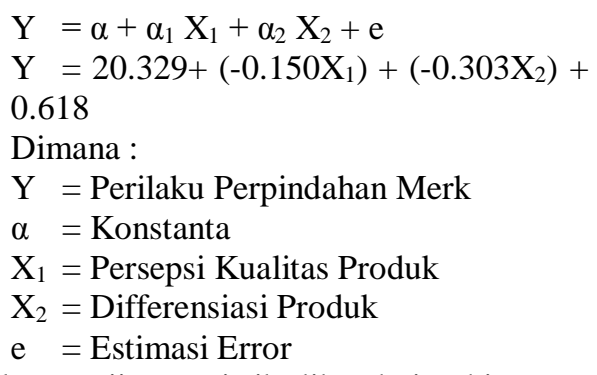
Hasil pengujian statistik diketahui $\mathrm{F}$ hitung = $95.735>3.09$ maka artinya semua variabel 
Xsecara bersama-sama memiliki pengaruh yang signifikan terhadap Y.

\section{KESIMPULAN DAN SARAN}

Berdasarkan hasil perhitungan analisis regresi linier berganda dari pengujian hipotesis dan pembahasan hasil penelitian dapat ditarik kesimpulan sebagai berikut :

1. Persepsi Kualitas Produk Berpengaruh negative dan signifikan terhadap Perilaku Perpindahan Merk Sepeda Motor Yamaha. Hal ini terlihat dari hasil analisis mengunakan bantuan program SPSS dapat diketahui bahwa nilai $\mathrm{T}_{\text {hitung }}$ yang dihasilkan lebih besar dari $\quad \mathrm{T}_{\text {tabel }}$ dengan taraf signifikasi yang lebih keci dari 0.05 (dapat dilihat pada tabel). hal ini dapat disimpulkan bahwa hipotesi $\mathrm{H}_{0}$ ditolak dan $\mathrm{H}_{\mathrm{a}}$ diterima. Atau terdapat pengaruh yang signifikan antara kualitas produk terhadap perilaku perpindahan merk. Disamping itu pula dapat diketahui bahwa kualitas produk Yamaha di persepsikan kategori cukup oleh masyarakat, hal ini mendorong konsumen untuk berpindah merk ke merk lain. Berdasarkan indeks jawaban responden didapat bahwa responden melakukan perpindahan merk sepeda motor Yamaha diakibatkan penilaian kualitas motor Yamaha dari segi kinerja mesin Yamaha cepat panas (overheat) $36.4 \%$, kinerja fungsi yaitu tidak nyaman untuk bepergian $35.2 \%$, harga jual kembali $35.2 \%$, konsumsi bahan bakar $35.2 \%$, kemudahan perbaikan $35.2 \%$. atas alas an tersebut secara keseluruhan persepsi kualitas Yamaha rata-rata pada kategori cukup, secara niai kategori cukup, tetapi akibat persaingan sempurna di kategori industry ini, nilai cukup masih sulit untuk bersaing. Oleh karena itu perpindahan merk sepeda motor Yamaha menjadi sangat tinggi.

2. Differensiasi Produk Berpengaruh negative dan signifikan terhadap Perilaku Perpindahan Merk Sepeda Motor Yamaha. Hal ini bisa di lihat dari hasil analisis mengunakan bantuan program SPSS dapat diketahui bahwa nilai $\mathrm{T}_{\text {hitung }}$ yang dihasilkan lebih besar dari

$\mathrm{T}_{\text {tabel }}$ dengan taraf signifikasi yang lebih kecil dari 0.05 (dapat dilihat pada tabel ). hal ini dapat disimpulkan bahwa hipotesi $\mathrm{H}_{0}$ ditolak dan $\mathrm{H}_{\mathrm{a}}$ diterima. Atau terdapat pengaruh yang signifikan antara differensiasi produk terhadap perilaku perpindahan merk. Disamping itu pula dapat diketahui bahwa differensiasi produk Yamaha di persepsikan kategori buruk oleh masyarakat, hal ini mendorong konsumen untuk berpindah merk. Berdasarkan indeks jawaban responden didapat bahwa responden melakukan perpindahan merk sepeda motor Yamaha diakibatkan penilaian differensiasi produk sepeda motor Yamaha dari segi estetika bentuk50 $\%$, fitur tambahan $30 \%$, fungsi keluarga 35\%, fungsi jarak jauh $36 \%$, fungsi pengguna wanita $35 \%$. atas alasan tersebut secara keseluruhan persepsi kualitas Yamaha rata-rata pada kategori buruk, maka dari itu merk Yamaha suit bersaing di kategori industry ini, Oleh karena itu perpindahan merk sepeda motor Yamaha menjadi sangat tinggi. Persepsi Kualitas Produk dan Differensiasi Produk Berpengaruh signifikan terhadap Perilaku Perpindahan Merk Sepeda Motor Yamaha. Hal ini bisa dilihat dari hasil analisis mengunakan bantuan program SPSS dapat diketahui bahwa nilai $F_{\text {hitung }}$ yang dihasilkan lebih besar dari $\quad F_{\text {tabel }}$ dengan taraf signifikasi yang lebih kecil dari 0.05 (dapat dilihat pada tabel ). hal ini dapat disimpulkan bahwa hipotesi $\mathrm{H}_{0}$ ditolak dan $\mathrm{H}_{\mathrm{a}}$ diterima. Atau secara simultan terdapat pengaruh yang signifikan antara kualitas produk dan differensiasi produk terhadap perilaku perpindahan merk. Di samping itu juga diketahui koefisien determinasi $R$ Square sebesar 0.667 yang memiliki arti bahwa pengaruh variabel persepi kualitas produk dan differensiasi produk terhadap perilaku perpindahan merk adalah sebesar $66.4 \%$ dan sisanya $33.6 \%$ dipengaruhi oleh variable lain diluar model penelitian.

\section{SARAN}

Adapun saran penelitian ini adalah sebagai berikut :

1. Bagi Perusahaan

Perilaku perpindahan merk sepeda motor Yamaha tergolong cukup tinggi, ini disebabkan rendahnya persepsi kualitas produk dan differensiasi produk. Ini bisa dilihat daqri indeks jawaban responden mendapat nilai yang rendah. Maka dari itu perusahaan harus meningkatkan persepsi yang baik terhadap kualitas produk dan terus berinovasi dalam mendifferensiasikan produk agar mendapat nilai yang baik dari pelanggan.

2. Bagi Penelitian Selanjutnya

Bagi penelitian selanjutnya hal
yang dapat dijadikan sebagai
pertimbangan yaitu dikarenakan
kemampuan prediksi dari dua variabel
independen terhadap Perilaku
perpindahan merek sebesar $66.4 \%$,
sedangkan sisanya $33.6 \%$ dipengaruhi
oleh faktor-faktor lain di luar model
regresi. Maka bagi penelitian selanjutnya
disarankan untuk menambah atau
menggunakan larinnya yang potensial
independen lainnabel-variabel


memberikan kontribusi terhadap perilaku perpindahan merk sepeda motor Yamaha.

Untuk penelitian selanjutnya agar menggunakan responden dengan teknik sampling dan metode yang berbeda untuk melihat perbandingan antara satu metode dengan metode lainnya.

\section{DAFTAR PUSTAKA}

Ahmad Mardalis. 2005. Meraih Loyalitas Pelanggan. Jakarta : Balai Pustaka

Anandhito B A. 2011. Pengaruh Atribut Produk, Harga, Kebutuhan Mencari Variasi Baru, dan Ketidakpuasan Konsumen terhadap keputusan perpindahan merk dari samsung galaxy series. Malang : Universitas Dipenogoro.

Durianto, Darmadi, Sugiarto dan Lie Joko Budiman. (2004). Brand Equity Ten Strategi Memimpin Pasar. Jakarta : Gramedia Pustaka Utama

F Rangkuti, 2008. The Power Of Brand. Jakarta : Gramedia Pustaka Utama

F Tjiptono, 2012. Service Manajemen. Jakarta : C.V Andi Offset ----------, 2012.Brand Equity:

Konseptualisasi dan

Pengukuran.Jakarta: C. V Andioffset

Ghozali, Imam. 2009. Eknmetrika Teri Knsep dan Aplikasi dengan SPSS 17.Semarang: BP UNDIP

Hermawan Kartajaya. 2004. Postioning, Differensiasi dan Brand. Jakarta : Gramedia Pustaka Utama

J Pratama Sahetapy, 2013. Differensiasi Produk, Strategy Merk PengaruhnyaTerhadap Keputusan Pembelian Meubel UD Sinar Sakti. Kediri : Universitas Brawijaya

Kotler Philip dan Kevin Lane Keller, 2009. Manajemen Pemasaran Jilid1. Terjemahan : Benjamin Molan,Jakarta: Prenhallindo.

.2009. Manajemen Pemasaran Jilid2. Terjemahan : Benjamin Molan,Jakarta: Prenhallindo.

Peter, J. Paul dan Jerry C. Olson, 2010.
Consumer Behavior and Marketing Strategy, 6th. Ed. New York : Mc. Graw - Hill.

Suzy Widiasary (2008). Analisis

Perilaku Brand Switching

Konsumen dalam Pembelian Produk Sepeda Motor. Semarang :Universitas Stikubank.

SolomonM R, 2013. Customers

Behavior. London : Pearson

Education Ltd.

Tai Jacky dan Chew Wilson.2012.

Brand Management. Jakarta : PT Indeks

Tristiani Oktario, 2011. Analisa Pengaruh Kualitas Produk dan Persepsi Harga terhadap Keputusan Berpindah Merk pada Konsumen Pembalut wanita Kotek Semarang. Universitas Dipenogoro 